\title{
DIJAGNOSTIČKA VRIJEDNOST SREDNJEG VOLUMENA, BROJA TROMBOCITA I TROMBOKRITA U AKUTNOJ EMBOLIJI PLUĆA
}

\author{
Marina Berberović 1 , Danijel Pravdiće, \\ ${ }^{1}$ Centar urgentne medicine, Sveučilišna klinička bolnica Mostar, Bosna i Hercegovina \\ ${ }^{2}$ Klinika za interne bolesti, Sveučilišna klinička bolnica Mostar, Bosna i Hercegovina \\ ${ }^{3}$ Katedra za Fiziologiju, Medicinski fakultet Sveučilišta u Mostaru, Bosna i Hercegovina \\ Rad je primljen 1.3.2017. Rad je recenziran 19.3.2017. Rad je prihvaćen 10.4.2017.
}

\section{SAŽETAK}

UVOD: Trombociti imaju važnu ulogu u patogenezi tromboza, pa tako i plućne embolije, prije svega što su agregacija i stvaranje trombocitnih agregata dominantni u plućnoj emboliji. Veličina trombocita je povećana u razdoblju nakon tromboembolijskog incidenta, no značaj trombokrita i broja trombocita u plućnoj emboliji je nedovoljno poznat.

CILJ: Ispitati dijagnostičku vrijednost srednjeg volumena trombocita, broja trombocita i trombokrita u dijagnozi akutne plućne embolije.

ISPITANICI I METODE: U istraživanje je bilo uključeno 30 bolesnika koji su pri prijamu u bolnicu imali visoku sumnju na plućnu emboliju. Dijagnoza je potvrđena na osnovu promjena u elektrokardiogramu, povišenih vrijednosti D-dimera, računalnom višeslojnom tomografijom angiografijom, te scintigrafijom pluća. U bolesnika smo pratili broj trombocita, njihov srednji volumen, raspodjelu trombocita po volumenu, te udio trombocita u venskoj krvi (trombokrit). Kontrolnu skupinu su činili bolesnici dijabetičari, reumatološki bolesnici i bolesnici s hipertenzijom, koji su imali normalne vrijednosti D-dimera i nisu imali pridružena tromboembolijska stanja.

REZULTATI: Prosječna životna dob svih ispitanika u istraživanju bila je 70,65 $\pm 11,58$ godina. Prosječna vrijednost D-dimera u ispitivanoj skupini je iznosila $3465 \pm 1190$, što je bilo statistički značajno povećanje u odnosu na referentnu vrijednost $(\mathrm{p}<0,01)$. Ispitna i kontrolna skupina nisu se značajno razlikovale prema ukupnom broju trombocita u krvi $(\mathrm{p}=0,065)$. Srednji volumen trombocita nije se značajno razlikovao između ispitne i kontrolne skupine $(\mathrm{p}=0,100)$. Isto tako, između promatranih skupina nije bilo razlike $\mathrm{u}$ indeksu raspodjele trombocita po volumenu $(\mathrm{p}=0,327)$. $\mathrm{U}$ ispitnoj skupini, udio trombocita u krvi (trombokrit) bio je značajno manji nego u kontrolnoj skupini $(\mathrm{p}=0,044)$.

ZAKLJUČAK: Trombokrit je bio značajno smanjen u skupini bolesnika s akutnom plućnom embolijom,dok se vrijednosti trombocita, njihovog srednjeg volumena i raspodjela trombocita po volumenu nisu značajno razlikovali u bolesnika $s$ akutnom plućnom embolijom u odnosu na bolesnike u kontrolnoj skupini.

Ključne riječi: plućna embolija, srednji volumen trombocita, broj trombocita, raspodjela trombocita po volumenu, trombokrit.

Osoba za razmjenu informacija:

prof. dr. sc. Danijel Pravdić, dr. med.

tel: 063287623

e-mail: danijel.pravdic@sve-mo.ba

\section{UVOD}

Plućna embolija (PE) je bolest u kojoj dolazi do opstrukcije plućne arterije trombom. Izvor tromba najčešće su u duboke vene nogu ili zdjelice, a rjeđe desna klijetka ili gornja šuplja vena (1). Najčešća stanja koja povećavaju rizik za nastanak PE su duža imobilizacija nakon kirurških zahvata, maligne bolesti, trudnoća, korištenje oralnih kontraceptiva, aterosklerotske promjene krvnih žila i kongestivno 
srčano zatajivanje $(2,3)$. U hospitaliziranih bolesnika to je česta bolest s učestalosti oko 1-2 \% (4). Poremećaji koagulacije najčešće nastaju zbog trombocitoze, nakon kiruških zahvata, ozljeda, tijekom trudnoće ili pri korištenju oralnih kontraceptiva $(2,5,6)$. Trombociti imaju važnu ulogu u patogenezi tromboza, pa tako i PE, prije svega što su agregacija ili nagomilavanje trombocita i stvaranje staničnih agregata izraženi u PE (6). Veličina trombocita, tj. srednji volumen trombocita je pokazatelj njihove aktivacije i pokazano je da je u akutnoj plućnoj emboliji srednji volumen trombocita povećan u razdoblju nakon tromboembolijskog incidenta (8-11). Mehanizmi aktivacije trombocita u plućnoj emboliji su višestruki. Tako naprimjer, omotač trombocita sadrži glikoproteine koji su nužni za adheziju i agregaciju potrebnu za hemostazu. $U$ unutrašnjosti trombocita nalaze se alfa granule i guste granule. $U$ trombozi dolazi do aktivacije trombocita, stvaranja tromboksana A2, te otpuštanja sadržaja iz alfa granula iz gustih granula. Nadalje pokazano je da inhibitori aktivacije trombocita poput acetilsalicilne kiseline i klopidogrela smanjuju učestalost tromboembolijskih incidenata. Sprječavanje vezanja adenozin difosfata na receptore koji se nalaze na trombocitima dovodi do zaustavljanja aktivacije glikoproteinskog IIb/IIIa kompleksa i posljedično dovodi do inhibicije aktivacije trombocita (12). U aktivaciji trombocita može sudjelovati i aktivacija faktora zgrušavanja. Tako antikoagulans heparin, čiji je učinak ovisan o prisutnosti antitrombina II i koji inhibira čimbenike IX, Xa, XIa, XIIa, sprečava nastanak trombina, blokira učinak već stvorenog trombina, a u većim koncentracijama blokira i agregaciju trombocita $(13,14)$.

\section{CILJ}

Primarni cilj ovog istraživanja bio je istražiti dijagnostičku vrijednost broja, srednjeg volumena trombocita i trombokrita u akutnoj PE.

\section{ISPITANICI I METODE}

Ovo istraživanje je provedeno kao istraživanje slučajeva i kontrola. Provedeno je na Klinici za unutarnje bolesti Sveučilišne kliničke bolnice Mostar u razdoblju od 1. siječnja 2010. do 31. ožujka 2011. godine. Podatke o bolesnicima smo prikupljali u arhivi Klinike za unutarnje bolesti Sveučilišne kliničke bolnice Mostar.

U istraživanje su uključeni svi bolesnici sa dijagnozom PE hospitalizirani na Klinici za unutarnje bolesti Sveučilišne kliničke bolnice Mostar u istraživanom razdoblju.

Ispitanici su bili bolesnici koji su na prijamu u bolnicu imali visoku sumnju na plućnu emboliju (broj bodova prema Wellsu veći od 3 i pozitivan test D-dimera) (6).

Kontrolnu skupinu činili su bolesnici koji su prema dobi i spolu odgovarali ispitivanoj skupini, a koji nisu imali tromboembolijskih incidenata i koji nisu koristili lijekove koji mogu utjecati na funkciju trombocita (antiagregansi, antikoagulansi i fibrinolitici).

U bolesnika smo pratili dob, spol, broj trombocita, srednji volumen trombocita, raspodjelu trombocita po volumenu, udio trombocita u krvi (trombokrit) i vrijednosti D-dimera. Svim bolesnicima je pri prvom pregledu snimljen standardni elektrokardiogram u 12 odvoda. Pratili smo srčanu frekvenciju, a budući da pri opsežnoj emboliji mogu postojati i simptomi akutne plućne hipertenzije (devijacija QRS osi u desno, visok p-val) i promjene ST segmenta i T-vala koje govore za naprezanje desne klijetke (inferiorni odvodi u elektrokardiogramu), također analizirane se i promjene $\mathrm{T}$ vala i ST spojnice $u$ tim odvodima. Bolesnicima je nakon stabilizacije kliničkog stanja učinjena perfuzijska scintigrafija pluća.

Kvantitativno određivanje D-dimera vršeno je u središnjem laboratoriju Sveučilišne kliničke bolnice Mostar s pomoću brzog imunotesta lateksom, na instrumenu BCS System (Siemens, Njemačka). Uzorci venske krvi su izvađeni odmah po prijamu, te su pohranjeni u citratom obložene epruvete do mjerenja D-dimera. Raspon normalnih vrijednosti D-dimera prema laboratorijskoj kalibraciji je ispod $450 \mathrm{u} / \mathrm{l}$.

Ventilacijsko-perfuzijska scintigrafija pluća je vršena udisanjem ugljikovih čestica obilježenih radioaktivnim tehnecijem 99. Smjesa je udisana u obliku aerosola. Nakon udisanja tehnecija, bolesnici su primili makro agregate albumina obilježene tehnecijem 99. Gama kamere (Siemens, model Orbiter 
75 i Mediso, model Dual Head Spect, Njemačka) korištene su pri snimanju osam ventilacijsko-perfuzijskih snimaka pluća. Dobivene slike su analizirali specijalisti nuklearne medicine. Vjerojatnost PE je procjenjena na osnovi postotka plućne perfuzije koji nije bio usklađen s plućnom ventilacijom. Iz istraživanj su bili isključeni svi ispitanici koji imaju pridruženu tromboembolijsku bolest (infarkt miokarda, angina pektoris, duboka venska tromboza, moždani udar i dr.) koja može značajno promijeniti broj i srednji volumen trombocita.

Nominalne varijable $\mathrm{u}$ istraživanju analizirale su se $\chi^{2}$ testom. Za kontinuirane varijable $u$ istraživanju prvo se analizirala normalnost njihove raspodjele s pomoću Kolmogorov-Smirnov testa. Za prikaz srednje vrijednosti i mjera raspršenja koristila se aritmetička sredina i standardna devijacija zbog normalno distribuiranih kontinuiranih varijabli, a za njihovu usporedbu Studentov t-test. Mogućnost pogrješke prihvatila se pri $\alpha<0,05$ te su razlike između skupina bile prihvaćene kao statistički značajne za $\mathrm{p}<0,05$.

Za statističku analizu dobivenih podataka korišten je programski sustav SPSS for Windows (inačica 13.0, SPSS Inc, Chicago, Illinois, SAD) i Microsoft Excell (inačica 11. Microsoft Corporation, Redmond, WA, SAD).

\section{REZULTATI}

Prosječna životna dob svih ispitanika u istraživanju bila je 70,65 $\pm 11,58$ (aritmetička sredina \pm standardna devijacija) godina. Najmlađi ispitanik imao je 34, a najstariji 95 godina. Ispitna i kontrolna skupina nisu se značajno razlikovale po dobi (Studentov $\mathrm{t}$-test $=0,255 ; \mathrm{p}=0,800$ ).

U istraživanju je bilo približno jednako ispitanika muškog spola ( $\mathrm{n}=32 ; 49,2 \%)$ i ženskog spola $(\mathrm{n}=33$; $50,8 \%)\left(\chi^{2}\right.$ test $=0,01$; s.s. $\left.=1 ; p=0,901\right)$, te se omjer muškog i ženskog spola nije značajno razlikovao između ispitivane i kontrolne skupine ( $\chi^{2}$ test $=0,39$; s.s. $=1 ; \mathrm{p}=0,531)$ (Slika 1).

U $20(62,5 \%)$ od 32 ispitanika bila ja prisutna elevacija ST spojnice u inferiornim elektrokardiografskim odvodima, dok je negativan $\mathrm{T}$ val bio prisutan u 16 (50 \%) ispitanika u istim odvodima. Prosječna vrijednost D-dimera u ispitivanoj skupini je iznosila $3465 \pm 1190$, što je statistički značajno povećanje $\mathrm{u}$ odnosu na referentnu vrijednost (t-test za jedan uzorak=13,41; $\mathrm{p}<0,01)$.

Ispitna i kontrolna skupina nisu se značajno razlikovale prema ukupnom broju trombocita u krvi (Studentov t-test=1,878; $\mathrm{p}=0,065)($ Slika 2).

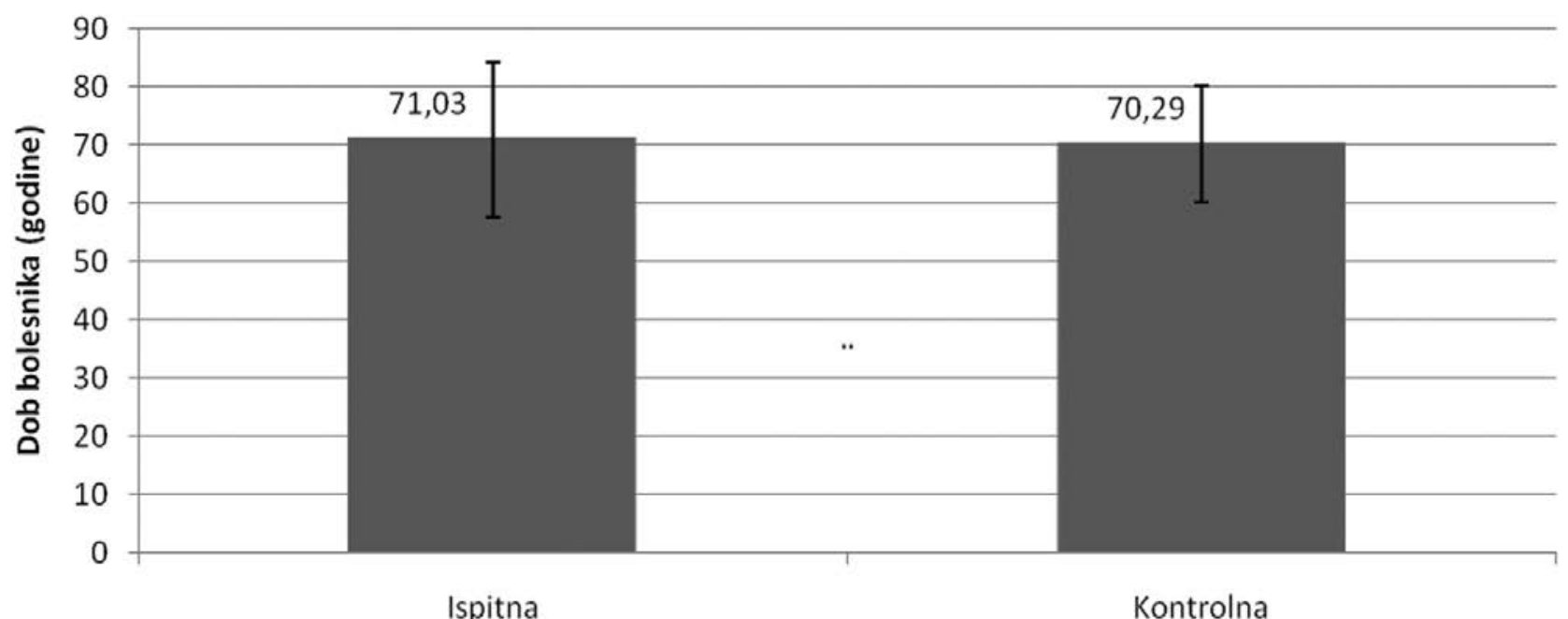

\section{Skupina}

Slika 1. Prikaz raspodjele bolesnika prema dobi. 
Berberović M, Pravdić D. Dijagnostička vrijednost srednjeg volumena, broja trombocita i trombokrita u akutnoj emboliji pluća. Zdravstveni glasnik. 2017;1:19-28.

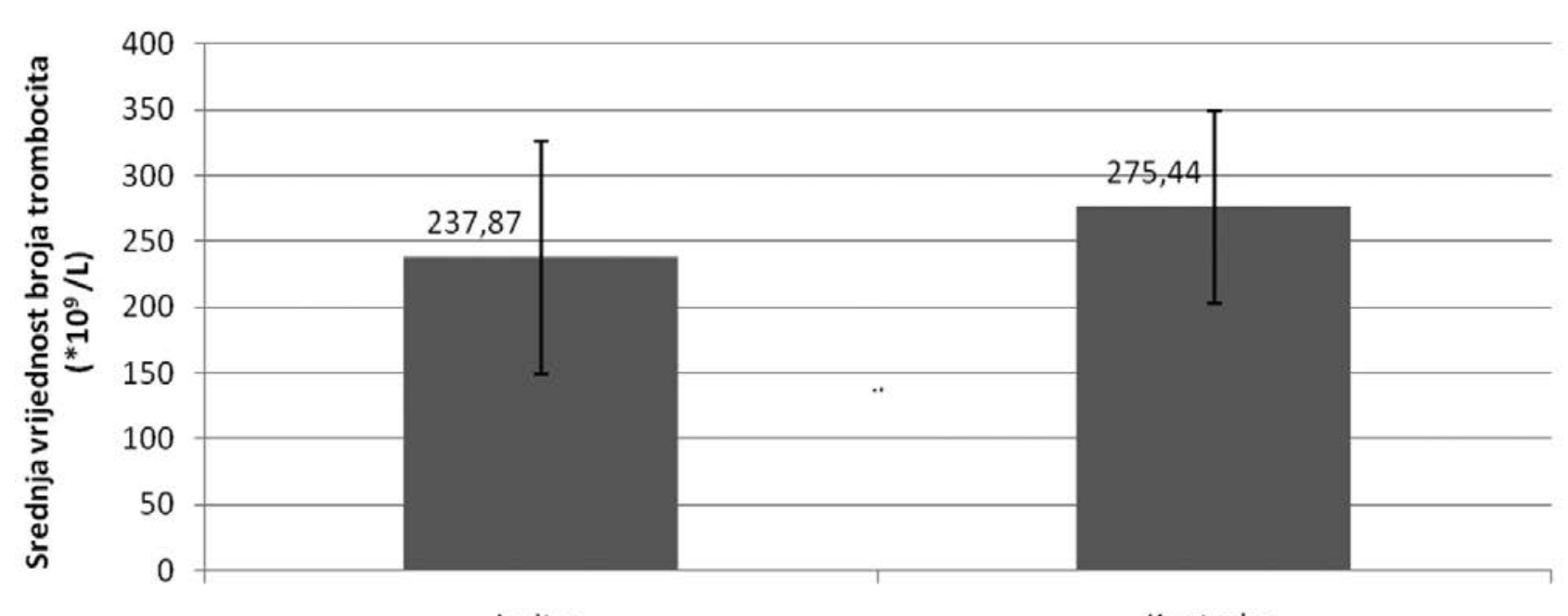

Ispitna

Kontrolna

\section{Skupina}

Slika 2. Broj trombocita u ispitivanoj i kontrolnoj skupini.

Srednji volumen trombocita nije se značajno razlikovao između ispitne i kontrolne skupine (Studentov t-test $=1,672 ; \mathrm{p}=0,100)$ (Slika 3).

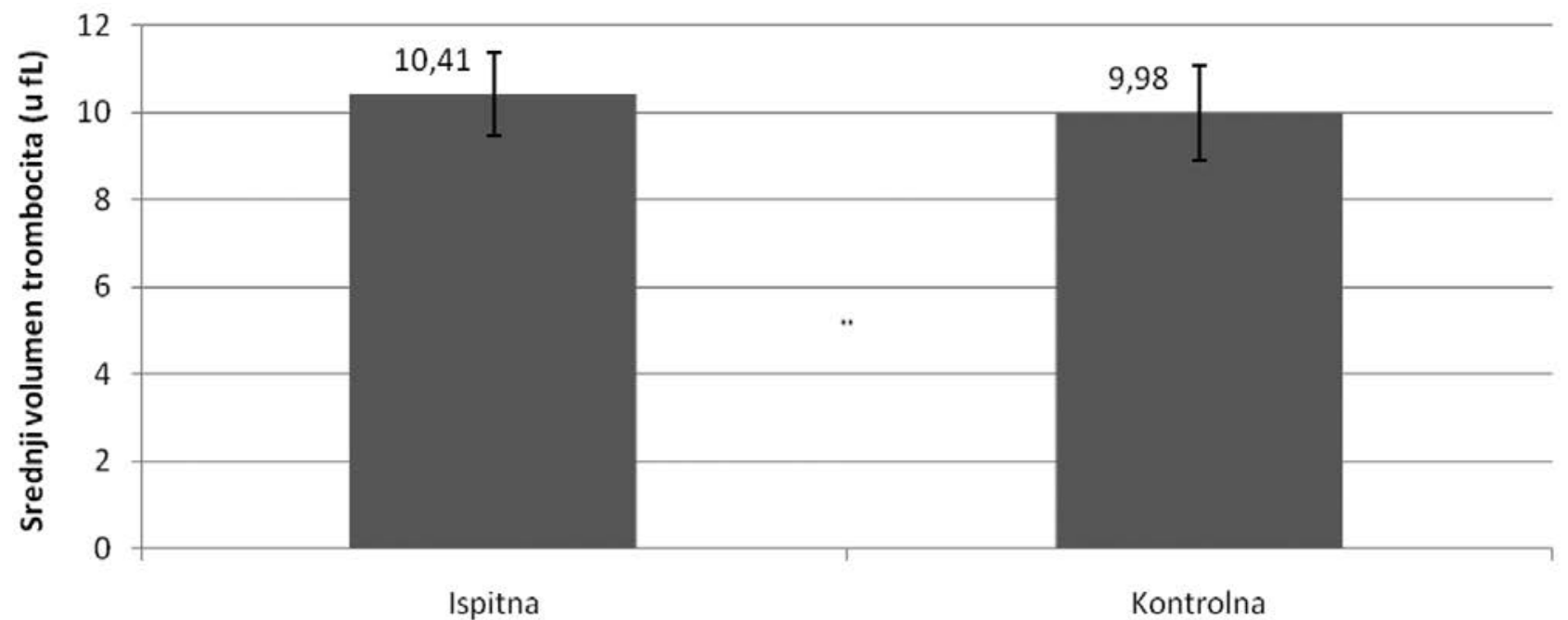

\section{Skupina}

Slika 3. Prikaz vrijednosti srednjeg volumena trombocita u ispitivanoj i kontrolnoj skupini.

Isto tako, između promatranih skupina nije se značajno razlikovao niti indeks raspodjele trombocita po volumenu (Studentov t-test $=0,989 ; \mathrm{p}=0,327$ ) (Slika 4). 


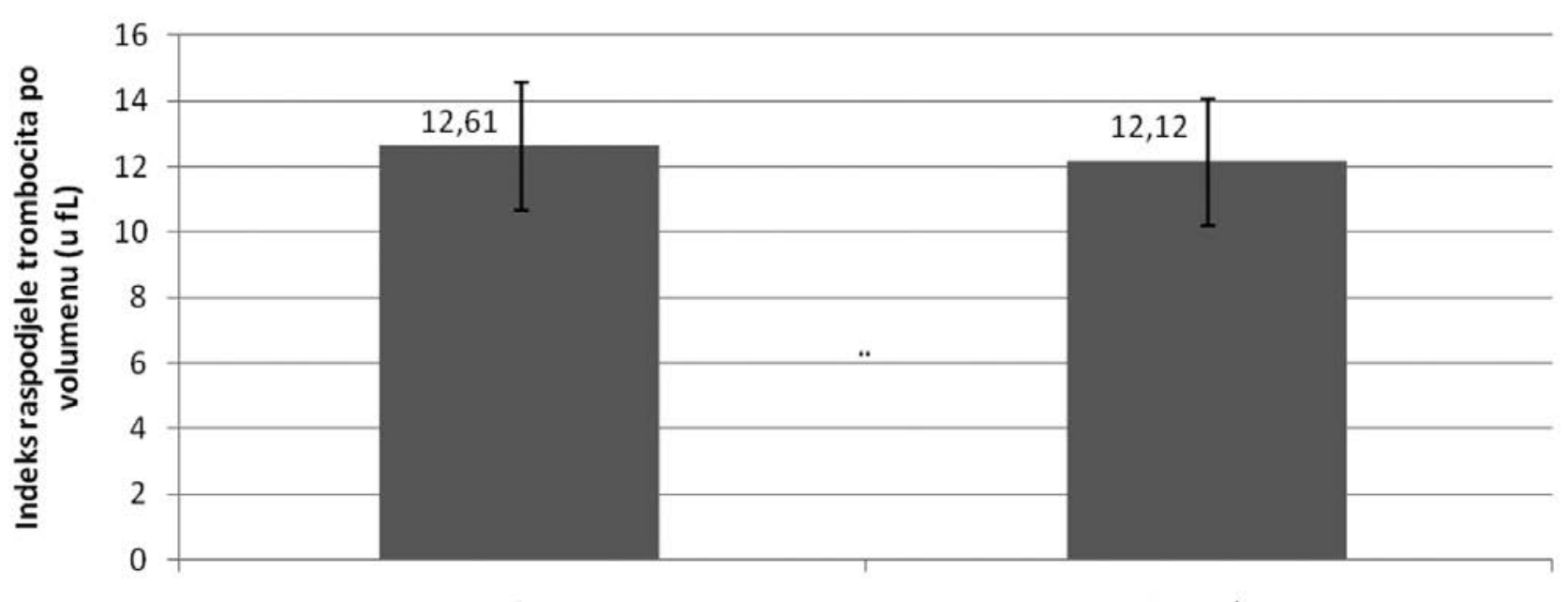

Ispitna

Kontrolna

Skupina

Slika 4. Indeks raspodjele trombocita u ispitnoj i kontrolnoj skupini.

U ispitnoj skupini, udio trombocita u krvi (trombokrit) bio je značajno manji nego u kontrolnoj skupini (Studentov t-test=2,050; $\mathrm{p}=0,044)$ (Slika 5).

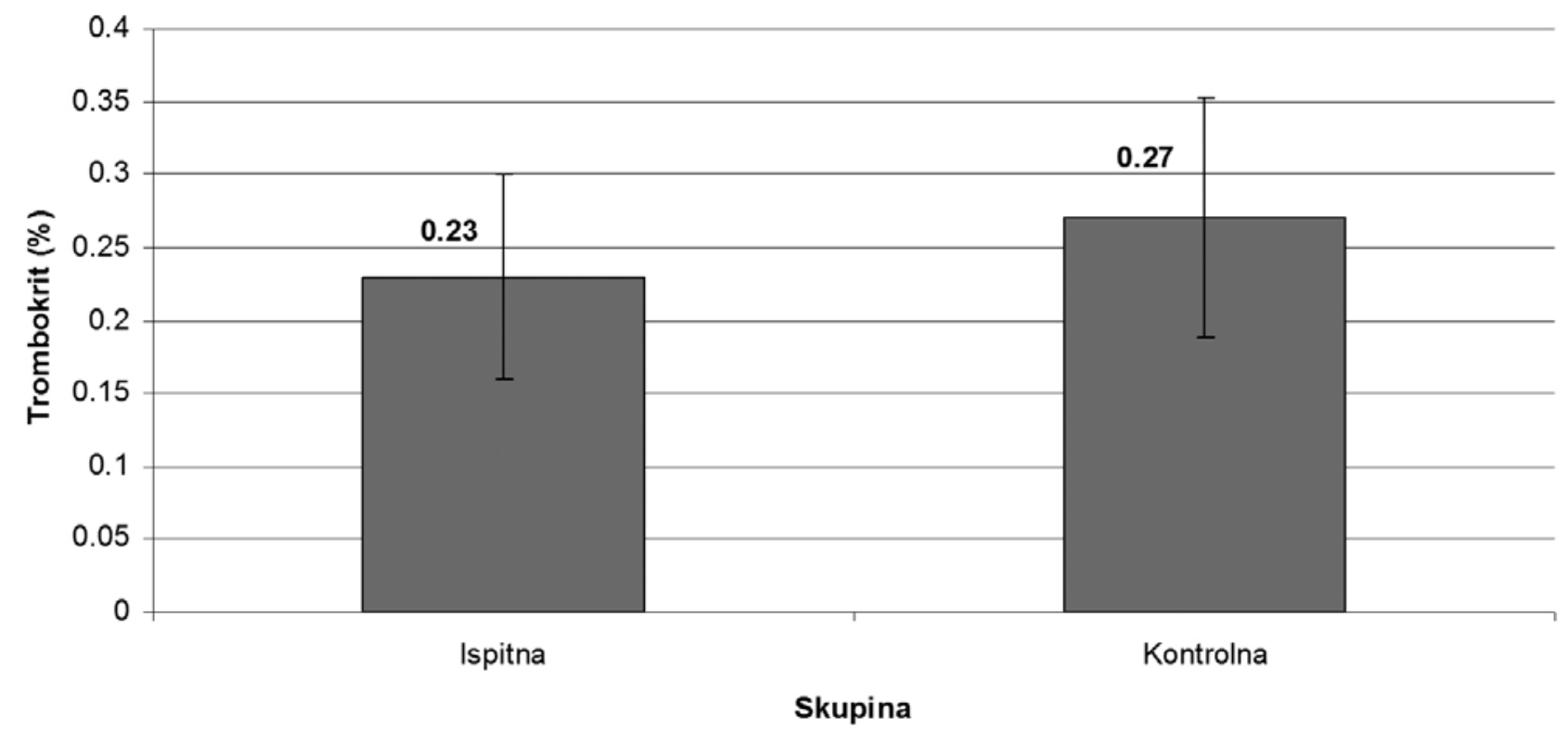

Slika 5. Prikaz vrijednosti trombokrita u bolesnika s plućnom embolijom i bolesnika u kontrolnoj skupini

\section{RASPRAVA}

U ovo istraživanje je uključeno 14 bolesnika muškog spola i 17 ženskog spola koji su na prijemu imali visoku sumnju na PE. Analizirali smo promjene broja trombocita, prosječnog volumena trombocita, raspodjele trombocita po volumenu i udjela trombocita $\mathrm{u}$ krvi u akutnom stadiju PE. Udio trombocita $\mathrm{u}$ krvi je bio značajno smanjen, a to je bilo povezano sa blagim smanjenjem broja trombocita i povećanjem prosječnog volumena trombocita $\mathrm{u}$ odnosu na kontrolnu skupinu. Raspodjela trombocita po volumenu nije bila značajno promijenjena. Ishodi ovog istraživanja upućuju da se u akutnom stadiju 
tromboembolijskih stanja kao što je PE primarno događa potrošnja trombocita, dok stvaranje trombocita nije značajno ubrzano.

Duboka venska tromboza i PE su još uvijek bolesti koje u velikom broju slučajeva dovode do smrtnog ishoda. Učestalost duboke venske tromboze je 48/100 000, a PE 69/100 000 (15-18). Nakon 50. godine života veći rizik imaju muškarci, a nakon 85 . godine učestalost te dvije bolesti značajno se povećava, te iznosi 1/100 stanovnika. Preko $100000 \mathrm{smr}$ ti svake godine je povezano s navedenim bolestima (18-20).

Broj i veličina trombocita, tj. srednji volumen trombocita pokazatelj je trombocitne aktivacije. Pokazano je da je srednji volumen trombocita povećan $\mathrm{u}$ tromboembolijskim stanjima (7-11,21). U istraživanju Bath i sur. pokazano je kako je u bolesnika $\mathrm{u}$ kojih je nastupio smrtni ishod nakon PE srednji volumen trombocita bio značajno veći nego u preživjelih bolesnika (10).

Vrijednosti srednjeg volumena trombocita u bolesnika u našem istraživanju su bile u granicama normalnih vrijednosti u obje ispitivane skupine. Ti ishodi se podudaraju s ostalim istraživanjima koja su pokazala da su vrijednosti srednjeg volumena trombocita $\mathrm{u}$ bolesnika s akutnom PE unutar normalnih vrijednosti. Ipak nešto više vrijednosti su $\mathrm{u}$ bolesnika s PE nego u kontrolnoj skupini, te su povezane s većom učestalosti smrtnog ishoda u tih bolesnika (10). Isto tako pokazano je kako je srednji volumen trombocita povezan s nastankom infarkta miokarda i moždanog udara $(10,22)$, te da je srednji volumen trombocita povećan u dubokoj venskoj trombozi donjih udova (9).

Indeks raspodjele trombocita po volumenu je jedan od ranih dijagnostičkih pokazatelja tromboembolijskih bolesti. Njegove povišene vrijednosti, zajedno s povišenim vrijednostima srednjeg volumena trombocita upućuju na aktivaciju trombocita (23-26). Povišene vrijednosti se pojavljuju i u akutnoj koronarnoj bolesti, te $\mathrm{u}$ tih bolesnika može poslužiti kao dijagnostički kriterij za prevenciju razvoja samog infarkta (26-30). U istraživanjima koja govore o tromboembolijskim bolestima dokazano je da su vrijednosti tog parametra više u bolesnika nego u zdravih ispitanika (30).

U istraživanjima u kojima je analiziran broj trombocita u PE, broj trombocita je bio u granicama normalnih vrijednosti, međutim njihov broj je manji u bolesnika s PE nego u kontrolnoj skupini (31-33). To je slično zapažanju koje smo imali u ovom istraživanju.

U ovom istraživanju analizirane su samo prve vrijednosti srednjeg volumena trombocita, odmah po prijemu bolesnika u bolnicu. Mogući razlog izostanka povećanja srednjeg volumena trombocita moglo bi biti kratko vremensko razdoblje od nastanka simptoma do uzimanja uzoraka krvi, gdje još uvijek nije došlo do potpune aktivacije trombocita koja bi bila zabilježena laboratorijskim nalazima (34). Isto objašnjenje se može dati za mjerenja indeksa raspodjele trombocita po volumenu. Indeks raspodjele trombocita po volumena je u obje skupine bio $\mathrm{u}$ granicama normalnih vrijednosti, s tim da je nešto viši bio u ispitivanoj skupini, iako nije bilo statistički značajne razlike između skupina. Ta dva parametra se najčešće promatraju zajedno, te upućuju na aktivaciju trombocita (34).

Činjenice da su bolesnici s PE imali nešto manju vrijednost trombocita (potrošna trombocitopenija) (35-38) u usporedbi s kontrolnom skupinom, a nešto više vrijednosti prosječnog volumena trombocita $\mathrm{i}$ indeksa raspodjele trombocita (pojačano stvaranje trombocita) govore u prilog kratkom vremenskom razdoblju od početka bolesti do uzimanja uzoraka krvi. Značajno smanjen trombokrit $\mathrm{u}$ ispitivanoj skupini nam govori da je u akutnoj PE dominantna potrošnja trombocita, dok stvaranje trombocita $u$ tom razdoblju bolesti nije u potpunosti aktivirano. Time se mogu objasniti i vrijednosti broja trombocita koje nisu bile povišene ni u jednoj skupini. Vrijednosti su u kontrolnoj skupini bile nešto više, iako u podatcima iz arhive za te bolesnike nije bilo podataka za bolesti povezane s zgrušavanjem krvi koje bi objasnile povišene vrijednosti. Dobiveni ishodi su u skladu s podatcima iz drugih studija (38).

Osim kratkog vremenskog razdoblja od početka PE do uzimanja prvih nalaza, mogući razlog ishoda dobivenih u ovom istraživanju moglo bi biti kratko 
vremensko razdoblje, od 15 mjeseci, te samim tim mali broj ispitanika uključenih u istraživanje. Planirano vremensko razdoblje je trebalo obuhvatiti razdoblje od 5 godina, međutim u dokumentaciji nismo našli podatke za vrijednosti srednjeg volumena trombocita i indeksa raspodjele po volumenu za bolesnike hospitalizirane ranijih godina. Samim tim bolesnici s PE hospitalizirani u tom razdoblju nisu mogli biti uključeni u ovo istraživanje. Dodatni čimbenik je prikupljanje podataka iz arhive, bez mogućnosti dobivanja dodatnih anamnestičkih podataka o pridruženim bolestima. Važnost prikupljanja podataka izravno od bolesnika bi bila u tome što bi tako bili sigurni da su sve bolesti koje mogu dati povišene vrijednosti ispitivanih parametara isključene. To se osobito odnosi na kontrolnu skupinu u kojoj je za očekivati da laboratorijski pokazatelji trombocitne aktivnosti budu u granicama normalnih vrijednosti.

Ako bi se isto ili slično istraživanje ponovo provodilo dobro bi bilo pratiti srednji volumen trombocita, indeks raspodjele trombocita po volumenu i broj trombocita kroz cijelo razdoblje hospitalizacije kako bi ispitali da li se vrijednosti tih parametara mijenjaju tijekom oporavka od PE i mogu li biti prediktor smrtnog ishoda u bolesnika s PE. Također korisno bi bilo usporediti njihove vrijednosti u bolesnika koji su imali smrtni ishod unutar 30 dana od pojave simptoma, s preživjelim bolesnicima, kako bi ispitali jesu li te vrijednosti više u najtežim oblicima bolesti.

U zaključku, ovo istraživanje je pokazalo da u akutnim stadijima PE dolazi do potrošnje trombocita i djelomične aktivacije njihove proizvodnje. Navedene promjene uzrokuju značajno smanjenje udjela trombocita u perifernoj krvi - trombokrita. Trombocitni indeksi prosječni volumen trombocita i volumen raspodjele trombocita nisu značajno povećani u akutnom stadiju $\mathrm{PE}$.

\section{ZAKLJUČCI}

1. Srednji volumen trombocita nije povećan u bolesnika s akutnom $\mathrm{PE}$, te nema značajne razlike u poređenju s kontrolnom skupinom.

2. Indeks raspodjele trombocita po volumenu također nije povećan u bolesnika s akutnom PE. Njegova srednja vrijednost kod ispitivane skupine je bila u granicama normalnih vrijednosti, te se nije značajno razlikovala od kontrolne skupine.

3. Broj trombocita je bio unutar normalnih vrijednosti u obje skupine bez statistički značajne razlike između ispitivanih skupina.

4. Udio trombocita u perifernoj krvi (trombokrit) značajno je bio smanjen u bolesnika s akutnom $\mathrm{PE} \mathrm{u}$ usporedbi s kontrolnom skupinom.

\section{LITERATURA}

1. Agnelli G, Becattini C. Acute pulmonary embolism. N Engl J Med. 2010; 363:266-74.

2. Sinescu C, Hostiuc M, Bartos D. Idiopathic venous thromboembolism and thrombophilia. J Med Life. 2011; 15;4:57-62.

3. DuttaTK, Venugopal V. Venous thromboembolism: the intricacies. JPostgradMed. 2009; 55:5564.

4. Mookadam F, Mookadam M, Jiamsripong p, Goel R. Pulmonary thromboembolic disease spectrum: diagnostic and therapeutic strategies. Expert Rev Cardiovasc Ther. 2009; 7:1421-8.

5. SakamotoK, YamamotoY, OkamatsuH, OkabeM. D-Dimer Is Helpful for Differentiating Acute Aortic Dissection and Acute Pulmonary Embolism from Acute Myocardial Infarction. The Hellenic Journao of Cardiology. 2011; 52:123-7.

6. Kakkar AK. Prevention of venous thromboembolism in general surgery. U: Colman RW, Clowes AW, George JN, Goldhaber SZ, Marder VJ, urednici. Hemostasis and Thrombosis: Basic Principles and Clinical Practice. 5th ed. Philadelphia, PA: Lippincott, Williams \& Wilkins; 2006:1361-67.

7. Guyton AC, Hall JE. Medicinska fiziologija. U: Kukolja Taradi S, Andreis I, urednici. Hemostaza i zgrušavanje krvi. 11 izdanje. Zagreb: Medicinska naklada; 2006. str 461-62.

8. Machin SJ, Briggs C. Mean platelet volume: a quick, easy determinant of thrombotic risk? J Thromb Haemost. 2010; 8:146-7.

9. Braekkan SK, Mathiesen EB, Njølstad I, Wilsgaard T, Størmer J, Hansen JB. Mean platelet volume is a risk factor for venous thromboem- 
bolism: the Tromsø Study, Tromsø, Norway. J

Thromb Haemost. 2010; 8:157-62.

10. Kostrubiec M, Łabyk A, Pedowska-Włoszek J, Hrynkiewicz-Szymanska A, Pacho S, Jankowski $\mathrm{K}$, i sur. Mean platelet volume predicts early death in acute pulmonary embolism. Heart. 2010; 96:460-5.

11. Bath P, Algert C, Chapman N, Neal B. Association of mean platelet volume with risk of stroke among 3134 individuals with history of cerebrovascular disease. Stroke. 2004; 35:622-6.

12. Stein PD, Matta F. Acute pulmonary embolism. Curr Probl Cardiol. 2010; 35:314-76.

13. TapsonVF. Acute pulmonary embolism. N Engl J Med. 2008; 358:1037-52.

14. Motte S, Samama CM, Guay J, Barré J, Borg JY, Rosencher N. Prevention of postoperative venous thromboembolism. Risk assessment and methods of prophylaxis. Can J Anaesth. 2006; 53:6879.

15. Merli GJ. Pathophysiology of venous thrombosis, thrombophilia, and the diagnosis of deep vein thrombosis-pulmonary embolism in the elderly. Clin Geriatr Med. 2006; 22:75-92.

16. White RH, Zhou H, Romano PS. Incidence of symptomatic venous thromboembolism after different elective or urgent surgical procedures. Thromb Haemost. 2003; 90:446-55.

17. Lyman GH, Khorana AA, Falanga A,Clarke-Pearson D, Flowers $\mathrm{C}$, Jahanzeb $\mathrm{M}$ i sur. American Society of Clinical Oncology. American Society of Clinical Oncology guideline: recommendations for venous thromboembolism prophylaxis and treatment in patients with cancer. J Clin Oncol. 2007; 25:5490-505.

18. Levine MN, Lee AYY, Kakkar AK. Cancer and Thrombosis. U: Colman RW, Clowes AW, George JN, Goldhaber SZ, Marder VJ, ur. Hemostasis and Thrombosis: Basic Principles and Clinical Practice. 5th ed. Philadelphia, PA: Lippincott, Williams \& Wilkins; 2006: 1251-62.

19. Torbicki A, Perrier A, Konstantinides S, Agnelli G, Galie N, Pruszczyk P, i sur. Guidelines on the diagnosis and management of acute pulmonary embolism: the Task Force for the Diagnosis and
Management of Acute Pulmonary Embolism of the European Society of Cardiology (ESC). Eur Heart J. 2008; 29:2276-315.

20. Geerts WH, Bergqvist D, Pineo GF, Heit JA, Samama CM, Lassen MR, i sur. Prevention of Venous Thromboembolism: American College of Chest Physicians (ACCP) Evidence-Based Clinical Practice Guidelines (8th Edition). Chest. 2008: 381-453.

21. Kuriakose J, Patel S. Acute pulmonary embolism. Radiol Clin North Am. 2010; 48:31-50.

22. Narani K. Deepveinthrombosisandpulmonaryembolism - Prevention, management, and anaesthetic considerations.Indian J Anaesth. 2010; 54:8-17.

23. Sikka P, Bindra V.Newerantithromboticdrugs. Indian J Crit Care Med. 2010;14:188-195.

24.DavamiF, SardariS, Majidzadeh-AK, HemayatkarM, BarkhordariF, EnayatiS. A novel variant of t-PA resistant to plasminogen activator inhibitor-1; expression in CHO cells based on In Silico experiments. BMB reports. 2011; 44:34-9.

25. Hajduk B, Tomkowski WZ, Malek G, Davidson BL. Vena cava filter occlusion and venous thromboembolism risk in persistently anticoagulated patients: a prospective, observational cohort study. Chest. 2010; 137:877-82.

26. Endler G, Klimesch A, Sunder-Plassmann H, Schillinger M, Exner M, Mannhalter C, i sur. Mean platelet volume is an independent risk factor for myocardial infarction but not for coronary artery disease. Br J Haematol. 2002; 117:399-404.

27. Vizioli L, Muscari S, Muscari A. The relationship of mean platelet volume with the risk and prognosis of cardiovascular diseases. Int J Clin Pract. 2009; 63:1509-15.

28. Greisenegger S, Endler G, Hsieh K, Tentschert S, Mannhalter C, Lalouschek W. Is elevated mean platelet volume associated with a worse outcome in patients with acute ischemic cerebrovascular events? Stroke. 2004; 35:1688-91.

29. Jaumdally RJ, Varma C, Blann AD, MacFadyen RJ, Lip GY. Platelet activation in coronary artery disease: intracardiac vs peripheral venous le- 
vels and the effects of angioplasty. Chest. 2007;

132:1532-9.

30. Vretenbrant K, Ramström S, Bjerke M, Lindahl TL. Platelet activation via PAR4 is involved in the initiation of thrombin generation and in clot elasticity development. Thromb Haemost. 2007; 97:417-24.

31. Chung T, Connor D, Joseph J, Emmett L, Mansberg R, Peters R, i sur. Platelet activation in acute pulmonary embolism. J Thromb Haemost 2007; 5:918-24.

32. Waser G, Kathriner S, Wuillemin WA. Performance of the automated and rapid STA Liatest D-dimer on the STA-R analyzer. Thromb Res. 2005; 116:165-70.

33. Chung T, Emmett L, Khoury V, Lau GT, Elsik $\mathrm{M}$, Foo F, i sur. Atrial and ventricular echocardiographic correlates of the extent of pulmonary embolism in the elderly. J Am Soc Echocardiogr. 2006; 19:347-53.
34. Silverstein MD, Heit JA, Mohr DN, Petterson TM, O'Fallon WM, Melton LJ., III Trends in the incidence of deep vein thrombosis and pulmonary embolism: a 25-year population-based study. Arch Intern Med. 1998; 158:585-93.

35. Galson S. Prevention of deep vein thrombosis and pulmonary embolism. Public Health Rep. 2008; 123:420-1.

36. Vagdatli E,Gounari E,Lazaridou E,Katsibourlia E,Tsikopoulou F,Labriano I. Platelet distribution width: asimple, practical and specific marker of activation of coagulation. Hippokratia. 2010; 14:28-32.

37. Khandekar M, Khurana A, Deshmukh S, Inamdar A. Platelet volume indices in patients with coronary artery disease and acute myocardial infarction: an Indian scenario. J Clin Pathol. 2006;59: 146-9.

38. Varol E, Icli A, Uysal BA, Ozaydin M. Platelet indices in patients with acute pulmonary embolism. Scand J Clin Lab Invest. 2011;71: 163-7. 


\title{
DIAGNOSTIC VALUE OF PLATELET INDICES IN PATIENTS WITH ACUTE PULMONARY EMBOLISM
}

\author{
Marina Berberović ${ }^{1}$, Danijel Pravdiće, \\ ${ }^{1}$ Emergency Medicine Centre, University Clinical Hospital Mostar, Bosna i Hercegovina, \\ ${ }^{2}$ Internal Medicine Clinic, University Clinical Hospital Mostar and Department of Physiology, ${ }^{3}$ Faculty of \\ Medicine, University of Mostar, Bosnia and Herzegovina
}

\begin{abstract}
INTRODUCTION: Platelets have an important role in the pathogenesis of thrombosis, including pulmonary embolism, primarily in aggregation and the formation of platelet aggregates dominant in pulmonary embolism. The volume of platelet is increased in the period after the thromboembolic incident, but the significance of plateletcrit and platelet count is insufficiently known.

OBJECTIVE: Test diagnostic value of platelet indices in diagnosis of acute pulmonary embolism.

SUBJECTS AND METHODS: The study included 30 patients that on admission to hospital had a high suspicion of pulmonary embolism. The diagnosis was confirmed on the basis of changes in the electrocardiogram, elevated D-dimer, multilayered computer tomography angiography, and lung scintigraphy. We monitored platelet count, their mean volume, and distribution of platelets in the volume, and platelet mass in venous blood (plateletcrit). The control group consisted of the patients with diabetes, rheumatic patients and patients with hypertension, who had a normal D-dimer and had associated thromboembolic conditions.

RESULTS: The average age of respondents was $70.65 \pm 11.58$. The average value of D-dimer in the study group was $3465 \pm$ 1190 , which was a statistically significant increase when compared to the reference value $(\mathrm{p}<0.01)$. In the test group, the platelet mass in venous blood (plateletcrit) was significantly lower than in the control group $(\mathrm{p}=0.044)$.

CONCLUSION: Plateletcrit was significantly reduced in patients with acute pulmonary embolism, while platelets mean value and their distribution in volume were not significantly different in patients with acute pulmonary embolism when compared to the control group patients.
\end{abstract}

Key words: pulmonary embolism, mean platelet volume, platelet counts, platelet distribution in volume, plateletcrit

Correspondence:

Prof, Danijel Pravdić, MD, PhD.

Department of Physiology, Faculty of Medicine, University of Mostar

Phone: 063287623

e-mail: danijel.pravdic@sve-mo.ba 